\title{
International financial reporting standards (IFRS): A study of opinion of practitioners in Ludhiana city
}

\section{SARISHMA SHARMA}

Received : 25.05.2016; Revised : 17.08.2016; Accepted : 04.09.2016

\begin{abstract}
IFRS refers to the guidelines and rules that companies and organizations are required to follow while preparing and presenting their financial statements. Present paper attempts to study and analyse the opinion of practitioners with respect to the importance of IFRS, the need for IFRS, the adoption of IFRS and the implementation concerns. For the purpose of the study a sample of 120 respondents was selected from the list of practitioners working in Ludhiana city. These practitioners included the experts who are well versed with the preparation of annual reports such as chartered accountants, cost and works accountants, chartered financial analysts, companies secretaries, chief financial officers etc. It was found that there exists a positive relationship between the importance of IFRS and need for IFRS, importance of IFRS and adoption of IFRS, need for IFRS and adoption of IFRS. Based on factor analysis of the statements related to IFRS, the four major factor components were extracted i.e. comparability, problems, lowering costs and efficiency. Significant correlation was found between the work experience of the practitioners and comparability. It can be concluded that the importance of IFRS has increased all over the world.
\end{abstract}

KEY WORDS : IFRS, Factor analysis, Factor components

How to cite this paper : Sharma, Sarishma (2016). International financial reporting standards (IFRS): A study of opinion of practitioners in Ludhiana city. Internat. J. Com. \& Bus. Manage, 9(2) : 148-155. DOI: 10.15740/HAS/IJCBM/9.2/148-155. 